\title{
Priming of Polymorphonuclear Neutrophils by Atrial Natriuretic Peptide In Vitro
}

\author{
Christian J. Wiedermann, Monika Niedermühlbichler, and Herbert Braunsteiner \\ Department of Internal Medicine, Faculty of Medicine, University of Innsbruck, A-6020 Innsbruck, Austria
}

\begin{abstract}
In ischemia-reflow states of coronary artery disease, the activation of PMN precedes the initiation of tissue damage. Release of atrial natriuretic peptide (ANP) from myocytes occurs within minutes after the onset of myocardial ischemia, which suggests a possible role of ANP in PMN activation. To investigate this possibility, we tested the effects of ANP on functions of PMN in vitro. ANP is a potent signal for priming the PMN respiration burst to secrete superoxide anion. Phorbol 12-myristate 13-acetate, opsonized zymosan, or FMLP could all be used as triggering stimuli to demonstrate the priming of PMN activation by ANP. Only ANP fragments 1-28 and 7-28 enhanced respiration burst activity but identical preparations of ANP fragments 13-18 or 1-11 failed to do so. This structureactivity relationship is typical of receptors for ANP found in other tissues. In addition, ANP stimulated the release of $\beta$-glucuronidase from PMN triggered by FMLP. The observed inhibition by ANP of FMLP-stimulated chemotaxis of PMN may be due to their enhanced adhesiveness. These data show that a classic cardiac hormone is involved in regulating important functional activities of PMN. These data support the possibility that ANP could act as a preinflammatory substance in ischemia-reperfusion states and myocardial necrosis. (J. Clin. Invest. 1992. 89:1580-1586.) Key words: chemotaxis • coronary artery disease - degranulation • ischemia-reperfusion injury • respiratory burst
\end{abstract}

\section{Introduction}

The observation that leukocyte depletion was associated with a significant reduction in infarct size in dogs subjected to coronary occlusion (1) suggests a role for polymorphonuclear neutrophils (PMN) in causing myocardial necrosis. Within minutes of occlusion of a major coronary artery, the PMN are activated (2), whereat they adhere to the vascular endothelium and migrate through the endothelial layer. Interactions with the endothelium can promote increased vascular resistance (3), diminished collateral flow, capillary blockade (4), predisposition to vasospasm (5), as well as enhanced vascular permeability (6). On subsequent reperfusion, entrapped PMN gain access to the previously ischemic region. Reperfusion of the ischemic myocardium increases the number of PMN distributed throughout the damaged region $(7,8)$.

Address reprint requests to Dr. Wiedermann, Department of Internal Medicine, Anichstrasse 35, A-6020 Innsbruck, Austria.

Received for publication 13 May 1991 and in revised form 5 December 1991.

J. Clin. Invest.

(C) The American Society for Clinical Investigation, Inc.

0021-9738/92/05/1580/07 \$2.00

Volume 89, May 1992, 1580-1586
In ischemia-reflow states of coronary artery disease with the development of arrythmias and myocardial infarction, reintroduction of oxygen to the ischemic or hypoxic tissue can cause an additional insult that is mediated in part by oxygen radicals (9). Generation of oxygen-derived radicals by PMN entering reoxygenated tissue is one of the potential sources of damage (10). Activated PMN depress both the uptake of $\mathrm{Ca}^{2+}$ by myocytes and the activity of $\mathrm{Ca}^{2+}$-stimulated, $\mathrm{Mg}^{2+}$-dependent ATPase. Because both of these activities can be prevented by free radical scavengers, it can be presumed that they are caused by oxygen-derived free radicals (11).

Activation and adhesion of PMN precede the initiation of tissue damage as determined histologically $(2,4,12,13)$. This observation suggests that PMN activation is not a response to tissue injury, but rather reflects other, more subtle changes resulting from the ischemic episode. Thus preinflammatory cytokines, such as tumor necrosis factor- $\alpha$ (TNF), ${ }^{1}$ are released early in myocardial infarction $(14,15)$ and may contribute to PMN activation (16). PMN-activating substances may be produced by endothelial cells upon hypoxia which dramatically modulates endothelial cell function $(17,18)$. In addition, superoxide anions that are produced by affected cells during ischemia (9) may directly promote PMN adhesion (19) and act on plasma to produce PMN chemotactic lipids (20). Other factors that could act as modulators of injury and inflammation in the ischemic heart are polypeptide hormones derived from perivascular nerves and/or other sources (21).

Atrial natriuretic peptide (ANP) may significantly contribute to the pathophysiological changes occurring in ischemia-reflow states of the heart in vivo, in that measurable release of ANP into coronary sinus blood and systemic circulation but not of other substances such as endothelin, vasoactive intestinal peptide, tachykinins, $\beta$-endorphin, and TNF- $\alpha$, has been reported to occur within minutes of balloon occlusion of a major coronary artery for angioplasty $(22,23)$. ANP is a 28amino acid polypeptide, secreted primarily by atrial myocytes in response to local wall stretch (i.e., increased intravascular volume or central venous pressure). The combined actions of ANP on vasculature, kidneys, and adrenals serve to reduce systemic blood pressure as well as intravascular volume (24). The heart atria represent the major site of synthesis of ANP. However, more recently ANP has been found in organs not immediately related to cardiovascular physiology: e.g., the nervous system, adrenals, lungs, and gut, as well as tissues belonging to the lymphatic, reproductive, or endocrine systems (25). Thus, ANP might have more physiological roles than originally thought of, one of them being modulation of inflammatory cells. However, the functional significance of ANP in tissues other than the cardiovascular system is, at present, poorly understood.

1. Abbreviations used in this paper: ANP, atrial natriuretic peptide; GM-CSF, granulocyte/macrophage colony-stimulating factor; NBT, nitroblue tetrazolium; TNF, tumor necrosis factor. 
Because of the important role of the PMN in responses occurring in ischemic events, we studied the in vitro effects of ANP on PMN. In this report we show that ANP primes PMN for an enhanced respiration burst activity in response to soluble stimuli. We show that: $(a)$ over the time course studied ANP without the additional presence of known PMN-activating factors such as FMLP, opsonized zymosan, or phorbol 12-myristate 13-acetate (PMA) does not activate PMN respiration burst activity, migration, or granule release; $(b)$ ANP activates PMN to increased respiration burst activity and granule release induced by coincubation with FMLP and zymosan, respectively, and decreases migration of PMN toward maximally stimulating concentrations of FMLP when simultaneously exposed to these agents; $(c)$ preincubation of PMN with ANP significantly enhances FMLP- or PMA-induced respiration burst activity; (d) the structure-activity relationship of ANP suggests a specific receptor-mediated effect of ANP on PMN, as ANP 1-28 and ANP 7-28 are active, whereas ANP 13-18 and ANP 1-11 are inactive as stimulants; $(e)$ because ANP does not stimulate cyclic GMP accumulation in the PMN after 10 min of exposure, the signaling mechanism for ANP may involve the ANP receptor subtype, which lacks guanylate cyclase activity on the cytoplasmic domain.

\section{Methods}

Materials used in these studies include ANP and ANP fragments (Sigma Chemical Co., St. Louis, MO; or Peninsula Laboratories, Inc., Belmont, CA), the recombinant human cytokines TNF- $\alpha$ (sp act 4 $\times 10^{7} \mathrm{U} / \mathrm{mg}$ protein; Genentech Inc., South San Francisco, CA), granulocyte/macrophage colony-stimulating factor (GM-CSF; sp act 5 $\times 10^{7} \mathrm{U} / \mathrm{mg}$ protein; Behring AG, Marburg, FRG), PMA and FMLP (Sigma Chemical Co.). ANP and its fragments were reconstituted in distilled water or $0.02 \mathrm{~N}$ acetic acid to stock solutions of $10 \mathrm{mmol} / \mathrm{liter}$, stored at $-20^{\circ} \mathrm{C}$, and freshly diluted to final concentrations in medium. FMLP was stored at $-20^{\circ} \mathrm{C}$ in DMSO at a concentration of 10 $\mathrm{mmol} /$ liter and was diluted into assay medium before use. PMA was reconstituted to $1 \mathrm{mg} / \mathrm{ml}$ in ethanol and also stored at $-20^{\circ} \mathrm{C}$. Zymosan was opsonized with fresh serum as follows: $100 \mathrm{mg}$ was suspended in $10 \mathrm{ml}$ of saline and heated at $100^{\circ} \mathrm{C}$ in a boiling water bath for $1 \mathrm{~h}$ with occasional shaking. The particles were washed three times in saline and incubated with $6 \mathrm{ml}$ of fresh human serum for $20 \mathrm{~min}$ at $37^{\circ} \mathrm{C}$ in a shaking water bath. The material was washed twice with saline and resuspended in saline to $50 \mathrm{mg} / \mathrm{ml}$. Opsonized zymosan was stored frozen at $-70^{\circ} \mathrm{C}$.

RPMI-1640, BSA, zymosan, nitroblue tetrazolium (NBT), Percoll, EDTA, dextran 485,000, iodoacetamide, ferricytochrome $c$, SOD, 4methylumbelliferone, 3-isobutyl-L-methylxanthine, and 4-methylumbelliferyl- $\beta$-D-glucuronide were from Sigma Chemical Co. Additionally, the following were purchased: Triton X-100 (New England Nuclear, Dreieich, FRG); Hanks' balanced salt solution (HBSS; Gibco, Vienna, Austria); sodium acetate (E. Merck \& Co., Darmstadt, FRG); and phosphoramidone (Peninsula Laboratories, Inc.).

Purification of human neutrophils. From the peripheral blood of healthy volunteers (anticoagulated with EDTA), PMN were obtained after discontinuous density gradient centrifugation of whole blood on Percoll or from buffy coat residues (mixed with normal saline in a ratio of 3:1) by dextran sedimentation and centrifugation through a layer of Ficoll-Hypaque as described (26), followed by hypotonic lysis of contaminating erythrocytes using sodium chloride solution. The cell preparations ( $>95 \%$ neutrophils by morphology in Giemsa stains, $>99 \%$ viable by trypan dye exclusion) were resuspended in RPMI-1640/0.5\% BSA for chemotaxis experiments, or in HBSS for respiration burst activity and exocytosis assays. The assays were performed in these media which also contained the test substances or their appropriate vehicles.
Respiration burst activity. NBT reduction by PMN was measured as described (26). To the cells $\left(100 \mu \mathrm{l}\right.$ of $2 \times 10^{6} \mathrm{PMN} / \mathrm{ml}$ in HBSS per well in 96-well microplates), NBT was added (final concentration (f/c) of $0.5 \mathrm{mg} / \mathrm{ml}$ ) with medium or test substances to a final volume of 200 $\mu \mathrm{l}$ per well. One vertical row of eight wells, in which the cells were preincubated for $10 \mathrm{~min}$ at $37^{\circ} \mathrm{C}$ with a $10-\mathrm{mmol} / \mathrm{liter}$ solution of iodoacetamide in HBSS served as reference. After gentle agitation on a microplate shaker, the amount of formazan accumulating in PMN during incubation in a humidified incubator at $37^{\circ} \mathrm{C}$ in $95 \%$ air $5 \%$ $\mathrm{CO}_{2}$ for the indicated time intervals was repeatedly quantitated in an ELISA reader at 550-nm wave length (model MR 700; Dynatech Labs, Guernsey, UK).

Measurement of the production of $\mathrm{O}_{2}^{-}$was based on the reduction of ferricytochrome $c$ by $\mathrm{O}_{2}^{-}$, the specificity of reduction being controlled by its inhibition by SOD. Immediately after preparation of PMN with or without exposure to test substances, $100 \mu \mathrm{l}$ per well of 2 $\times 10^{6} \mathrm{PMN} / \mathrm{ml}$ were immersed in a $160 \mu \mathrm{M}$ solution of ferricytochrome $c$ in phenol red-free HBSS containing $10 \mu \mathrm{M}$ FMLP or vehicle. To one vertical row, cytochrome $c$ containing $300 \mathrm{U} / \mathrm{ml} \mathrm{SOD}$ was added. This row served as a blank. The plates were covered with lids and placed in a $37^{\circ} \mathrm{C}$ humidified incubator with a $95 \%$ air-5\% $\mathrm{CO}_{2}$ atmosphere. At indicated time intervals, the plates were transferred to the ELISA reader and absorbances were read at $550 \mathrm{~nm}$. The absorbance values at $550 \mathrm{~nm}$ were converted to nanomoles of $\mathrm{O}_{2}^{-}$based on the extinction coefficient of (reduced minus oxidized) cytochrome $c$ : $\mathrm{OD}_{550 \mathrm{~nm}}=21 \times 10^{3} \mathrm{M}^{-1} \mathrm{~cm}^{-1}$. In that the vertical light path passing through $100 \mu \mathrm{l}$ of cytochrome $c$ was $3 \mathrm{~mm}$, calculated concentration of $\mathrm{O}_{2}^{-}$was $(\mathrm{nmol} \mathrm{O}-$ per well $)=($ absorbance at $550 \mathrm{~nm} \times 15.87)$ accord ing to reference 27 .

Chemotaxis. The chemotactic response of PMN to different gradients of FMLP and/or ANP was tested in a modified multiwell Boyden chamber as previously described (26). To the upper wells of the chemotaxis chamber 50,000 PMN were then added and the bottom wells were filled with $25 \mu \mathrm{l}$ of FMLP or ANP alone and in combination, or with $25 \mu \mathrm{l}$ of medium. The two wells were separated by a 3- $\mu \mathrm{m}$ pore-sized nitrocellulose filter (Sartorius, Göttingen, FRG) presoaked with medium. Chambers were incubated for $35 \mathrm{~min}$ at $37^{\circ} \mathrm{C}\left(5 \% \mathrm{CO}_{2}\right.$, fully humidified). Migration depth of the cells into the filter was microscopically measured (leading-front assay) in triplicates, after the cells and filters were fixed, dehydrated, and stained with hematoxylin (26).

Release of PMN granules. PMN granule release was determined by measuring exocytosis of $\beta$-glucuronidase (EC 3.2.1.31) as described (28). PMN were suspended in $0.9 \mathrm{ml}$ of HBSS at $2.5 \times 10^{7} / \mathrm{ml}$ and preincubated in a shaking water bath for $10 \mathrm{~min}$ at $37^{\circ} \mathrm{C}$. The cells were then stimulated by addition of $0.1 \mathrm{ml}$ of FMLP $(1.0 \mu \mathrm{mol} / \mathrm{liter})$, ANP 1-28 $(1.0 \mu \mathrm{mol} / \mathrm{liter})$, or a combination of FMLP $(1.0 \mu \mathrm{mol} / \mathrm{liter})$ and ANP 1-28 $(1.0 \mu \mathrm{mol} / \mathrm{liter})$ in HBSS, and the incubation was continued for 15 min under mild agitation in a water bath at $37^{\circ} \mathrm{C}$. The reaction was stopped by rapid cooling in ice followed by centrifugation at $800 \mathrm{~g}$ for $10 \mathrm{~min}$ at $4^{\circ} \mathrm{C}$. The supernatant was aspirated and diluted with a equal volume of $\mathrm{HBSS}$ containing $0.1 \%$ Triton $\mathrm{X}-100$. A suspension of the pellet was prepared with $1 \mathrm{ml}$ of HBSS containing $0.2 \%$ Triton $\mathrm{X}-100$, kept on ice during $20 \mathrm{~min}$ with occasional vortexing for extraction, diluted with $3 \mathrm{ml}$ of HBSS, and centrifuged at $800 \mathrm{~g}$ for $10 \mathrm{~min}$ at $4^{\circ} \mathrm{C}$. For assaying granule release, $\beta$-glucuronidase was measured in supernatants and pellet extracts by mixing $0.1 \mathrm{ml}$ of sample with $0.1 \mathrm{ml}$ of $10 \mathrm{mmol} /$ liter 4 -methylumbelliferyl- $\beta$-D-glucuronide in $0.1 \mathrm{~mol} /$ liter sodium acetate, $\mathrm{pH} 4.0$, containing $0.1 \%$ Triton X-100, and incubated for $15 \mathrm{~min}$ at $37^{\circ} \mathrm{C}$. The reaction was stopped by addition of 3.0 $\mathrm{ml}$ of $0.05 \mathrm{~mol} /$ liter glycine and $5 \mathrm{mmol}$ EDTA, $\mathrm{pH} \mathrm{10.4}$. Liberated 4-methylumbelliferone was measured fluorimetrically (excitation 365 nm, emission: $460 \mathrm{~nm}$ ) (Eppendorf, Hamburg, FRG). For standard curves, fluorimetric data obtained from dilutions of stock solutions containing $5 \mathrm{mmol} /$ liter 4-methylumbelliferone in ethanol (stored in the dark at $4^{\circ} \mathrm{C}$ ) were used.

Cyclic GMP assay. The cyclic GMP levels in the PMN were determined by means of a commercial radioimmunoassay kit (New England Nuclear). Samples containing $5 \times 10^{6} \mathrm{PMN}$ were resuspended in HBSS 


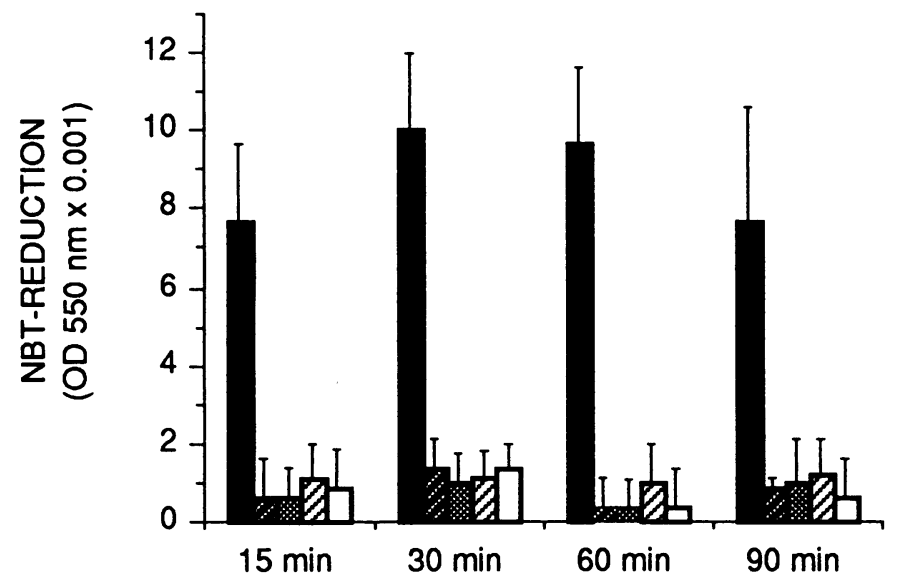

containing $0.5 \mathrm{mM}$ 3-isobutyl-L-methylxanthine and incubated in a shaking water bath at $37^{\circ} \mathrm{C}$. After $10 \mathrm{~min}, 100 \mathrm{nmol} /$ liter of ANP, 100 $\mathrm{ng} / \mathrm{ml}$ of PMA, or vehicle controls were added for additional $7 \mathrm{~min}$. Incubations were then terminated with centrifugation of the samples at $4^{\circ} \mathrm{C}$ for $3 \mathrm{~min}$ at $400 \mathrm{~g}$. Pellets were resuspended in $750 \mu \mathrm{l}$ of ice-cold $6 \%$ trichloroacetic acid (TCA) and centrifuged at $2,500 \mathrm{~g}$ for $20 \mathrm{~min}$, allowing the supernatants to be collected. TCA was eliminated by washing the extract five times with $5 \mathrm{ml}$ of water-saturated ethyl ether. Then, $500 \mu$ l of the samples was lyophilized and acetylated and cyclic GMP levels ( $\mathrm{fmol} / 10^{6} \mathrm{PMN}$ ) were determined by radioimmunoassay, as given by the manufacturer.

Calculations. The data is expressed as the mean and standard error of the mean (SEM). The nonparametrical analysis of variance was performed for independent samples after Kruskal-Wallis. Differences were compared using the Wilcoxon-Mann-Whitney test and a significant level designated $2 \alpha=0.05$. Statistics were performed using the StatView512+ software package (Abacus Concepts, Inc., Berkeley, CA).

\section{Results}

Effects of ANP alone on PMN functions. When PMN are incubated at $37^{\circ} \mathrm{C}$ for $0-90 \mathrm{~min}$ in the presence of $1 \mathrm{pmol} /$ liter to 1 $\mu \mathrm{mol} /$ liter of ANP 1-28, no significant iodoacetamide-inhibitable reduction of NBT (Fig. 1) or SOD-inhibitable reduction of

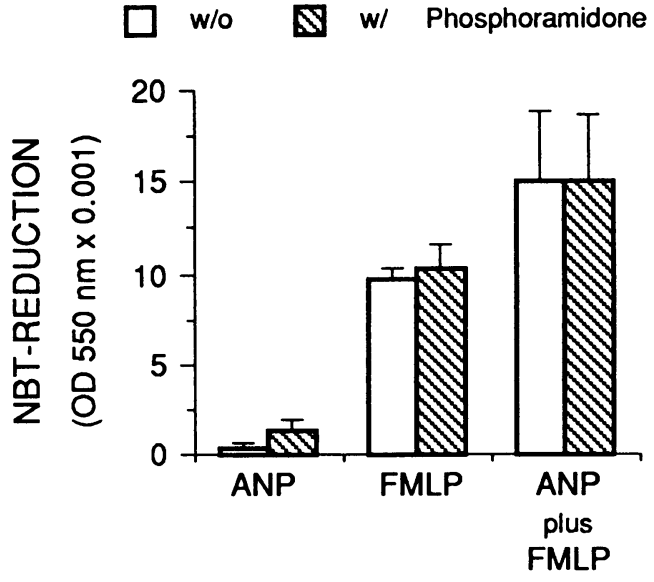

Figure 2. Stimulation of NBT reduction in PMN at 30 min of incubation $\left(37^{\circ} \mathrm{C}\right)$ by $10^{-8} \mathrm{M}$ of ANP 1-28 in the presence and absence of $10^{-6} \mathrm{M}$ of FMLP, with and without $10^{-5} \mathrm{M}$ of phosphoramidone. Bars represent the mean and SEM of determinations in replicates of eight from three independent experiments.

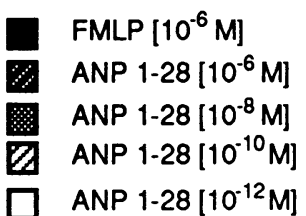

Figure 1. Stimulation of NBT reduction in PMN at 15, 30,60, and 90 min of incubation $\left(37^{\circ} \mathrm{C}\right)$ by $10^{-6} \mathrm{M}$ of FMLP vs. $10^{-6}, 10^{-8}, 10^{-10}$, and $10^{-12} \mathrm{M}$ of ANP 1-28. Bars represent the mean and SEM of determinations in replicates of eight from three independent experiments. ferricytochrome $c$ (not shown) occurs. Similarly, during the same time period $0.1 \mu \mathrm{mol} / \mathrm{liter}$ of ANP 1-28 does not cause chemotaxis of PMN into nitrocellulose micropores (see Fig. 6), nor does it induce release from PMN of $\beta$-glucuronidase ( $2.49 \%$ of total cellular $\beta$-glucuronidase at $100 \mathrm{nmol} /$ liter of ANP 1-28 compared to $2.45 \%$ for control untreated PMN after 15 min of incubation; mean, $n=5 ; P>0.1$; see Fig. 7).

Effects of ANP on agonist-induced PMN functions. Because PMN priming agents can enhance PMN responses to chemotactic factors, we examined the effect of ANP 1-28 on respiration burst activity of PMN in response to the chemotactic factors FMLP, zymosan, and PMA. Fig. 2 shows that, at a concentration $10 \mathrm{nmol} /$ liter ANP 1-28 enhances the reduction of NBT in PMN after $30 \mathrm{~min}$ of stimulation by $1 \mu \mathrm{mol} /$ liter of FMLP (enhancement after 15 and $60 \mathrm{~min}$ not shown). Addition of 10 $\mu \mathrm{mol} /$ liter of phosphoramidone to the incubation media does not affect NBT reduction in PMN exposed to ANP 1-28 alone, FMLP alone, or the combination of FMLP and ANP 1-28. NBT reduction was also enhanced by ANP 1-28 when PMN were exposed for a similar time period to $0.5 \mathrm{mg} / \mathrm{ml}$ of activated zymosan (Table I).

The dose dependency of the effect of ANP on NBT reduction is shown in Fig. 3. Both ANP 1-28 and a fragment with similar cardiovascular bioactivity, ANP 7-28 (29), increase in a dose-dependent fashion NBT reduction by PMN at $0.1 \mu \mathrm{mol} /$ liter of FMLP. Concentrations of ANP 1-28 or 7-28 that enhance FMLP-induced respiration burst activity were in the range of $0.1 \mathrm{nmol} / \mathrm{liter}$ to $1.0 \mu \mathrm{mol} / \mathrm{liter}$. In comparison to ANP 1-28 and ANP 7-28, which at a concentration of $10 \mathrm{nmol} /$ liter stimulate NBT reduction at $0.1 \mu \mathrm{mol} /$ liter of FMLP by $128 \%$ and $147 \%$, respectively, ANP $1-11$ and ANP $13-18$ at the

Table I. Stimulation of FMLP- or Opsonized Zymosan-induced Reduction of NBT by PMN in the Absence or Presence of ANP

\begin{tabular}{lcc}
\hline & \multicolumn{2}{c}{ NBT reduction at $30 \mathrm{~min}\left(\mathrm{OD}_{550 \mathrm{~nm}} \times 0.1\right)$} \\
\cline { 2 - 3 } & $\begin{array}{c}\text { FMLP } \\
\left(10^{-7} \mathrm{M}\right)\end{array}$ & $\begin{array}{c}\text { Opsonized zymosan } \\
(0.5 \mathrm{mg} / \mathrm{ml})\end{array}$ \\
\hline Control & $0.249 \pm 0.011$ & $0.175 \pm 0.010$ \\
ANP $1-28\left(10^{-7} \mathrm{M}\right)$ & $0.330 \pm 0.011$ & $0.247 \pm 0.012$ \\
$P$ value* & 0.0209 & 0.0209
\end{tabular}

Values are given as mean \pm SEM of four experiments each performed in replicates of eight. ${ }^{*}$ Wilcoxon-Mann-Whitney test, $n=4$. 


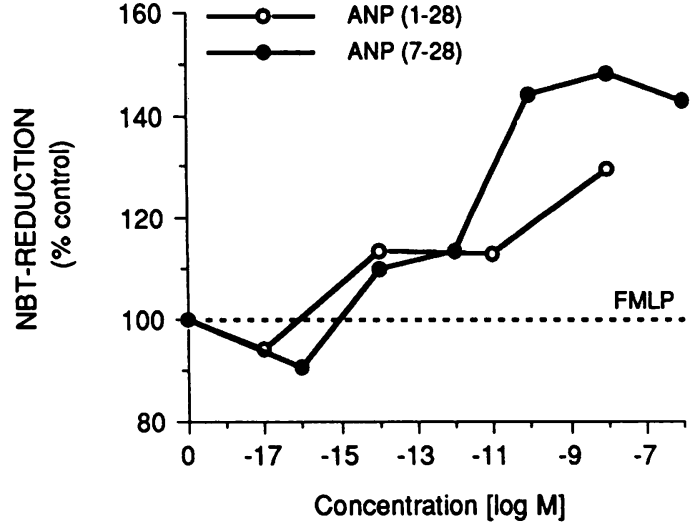

Figure 3. Stimulation by $10^{-7} \mathrm{M}$ of FMLP of the reduction of NBT at 30 min of incubation $\left(37^{\circ} \mathrm{C}\right)$ by $\mathrm{PMN}$ in response to the presence of various concentrations of ANP 1-28 $(0 ; n=4)$ or ANP 7-27 $(\bullet ; n=3)$. Each point represents the mean percent of control values obtained in independent experiments each performed in replicates of eight.
Table II. Effect of ANP or GM-CSF Pretreatment on Reduction of NBT by PMN Stimulated with FMLP

\begin{tabular}{|c|c|c|c|}
\hline \multirow[b]{2}{*}{$\begin{array}{l}\text { Preincubation } \\
\left(45 \text { min, } 37^{\circ} \mathrm{C}\right)\end{array}$} & \multicolumn{3}{|c|}{$\begin{array}{c}\text { NBT reduction at } 30 \min \left(\mathrm{OD}_{s 50 \mathrm{~nm}} \times 0.1\right) \text { with } \\
\operatorname{FMLP}\left(10^{-7} \mathrm{M}\right)\end{array}$} \\
\hline & Mean \pm SEM & $\begin{array}{l}\text { Percent } \\
\text { control }\end{array}$ & $P$ value* \\
\hline Control & $0.132 \pm 0.053$ & 100 & \\
\hline ANP $1-28\left(10^{-8} \mathrm{M}\right)$ & $0.153 \pm 0.054$ & 127.9 & 0.0463 \\
\hline ANP $7-28\left(10^{-8} \mathrm{M}\right)$ & $0.167 \pm 0.054$ & 138.6 & 0.0414 \\
\hline $\operatorname{ANP} 1-11\left(10^{-8} \mathrm{M}\right)$ & $0.132 \pm 0.047$ & 106.4 & 0.9784 \\
\hline ANP $13-18\left(10^{-8} \mathrm{M}\right)$ & $0.155 \pm 0.059$ & 113.2 & 0.2050 \\
\hline GM-CSF $(10 \mathrm{ng} / \mathrm{ml})$ & $0.161 \pm 0.055$ & 135.5 & 0.0414 \\
\hline
\end{tabular}

Spontaneous NBT reduction at $30 \mathrm{~min}$ of incubation at $37^{\circ} \mathrm{C}$ in the absence of FMLP of PMN that were preincubated for $40 \mathrm{~min}$ at $37^{\circ} \mathrm{C}$ in medium was $0.0014 \pm 0.0012$ (mean \pm SEM), $n=6$. ${ }^{*}$ Student's $t$ test (two-tailed, paired), $n=6$.

respiration burst activity after addition of FMLP, zymosan, or PMA.

We next determined the directed migration of PMN into nitrocellulose micropore filters stimulated by FMLP in the presence or absence of ANP 1-28. Maximal locomotion of PMN that were stimulated by FMLP occurs (after 35 min of incubation) at concentrations of 10-100 nmol/liter. Higher FMLP concentrations are less effective. In the presence of $0.1 \mu \mathrm{mol} /$ liter of ANP 1-28, significant reduction of maximal FMLP-induced chemotaxis can be observed (Fig. 6).

To further assess the effect of ANP on PMN stimulus-induced function, we evaluated PMN enzyme release during 15 min at $37^{\circ} \mathrm{C}$, measuring both total cellular and released amounts of $\beta$-glucuronidase in the absence of cytochalasin B. Fig. 7 shows that PMN treated with a combination of $0.1 \mu \mathrm{mol} /$ liter of FMLP and $0.1 \mu \mathrm{mol} / \mathrm{liter}$ of ANP 1-28 release significantly more lysosomal enzyme than PMN treated with 0.1 $\mu \mathrm{mol} /$ liter of FMLP alone.

Effect of ANP on cyclic GMP accumulation in PMN. There are two known receptor classes for ANP, one of which contains guanylate cyclase on the cytoplasmic domain and stimulates

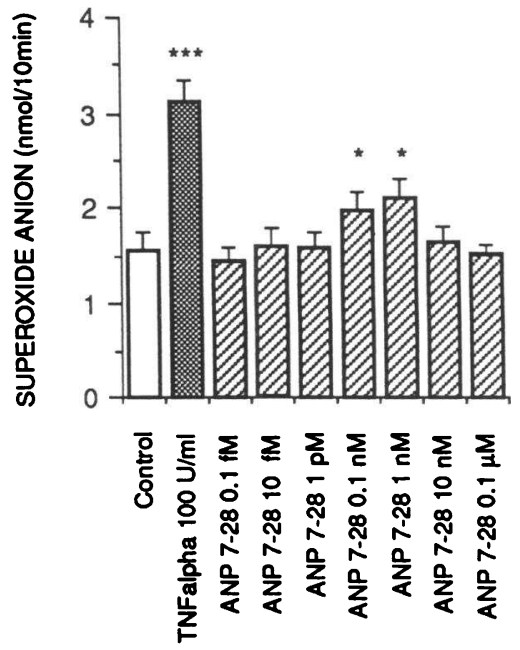

Figure 5. Stimulation of $10^{-7}$ M FMLP-triggered production of superoxide anion at $10 \mathrm{~min}$ of incubation $\left(37^{\circ} \mathrm{C}\right)$ by PMN by preincubation for $\mathbf{4 0}$ min with various concentrations of ANP $7-28$ or $100 \mathrm{U} / \mathrm{ml}$ of TNF- $\alpha$. Each point represents the mean and SEM obtained in four separate experiments each performed in replicates of eight. ${ }^{*} P<0.05$ (Wilcoxon-Mann-Whitney test). 
Table III. Stimulation by Pretreatment with ANP or TNF of PMA-triggered Superoxide Anion Production in PMN

\begin{tabular}{lrcc}
\hline & \multicolumn{3}{c}{ Superoxide anion secretion PMA $(50 \mathrm{ng} / \mathrm{ml})$} \\
\cline { 2 - 4 } $\begin{array}{c}\text { Preincubation } \\
\left(45 \text { min, } 37^{\circ} \mathrm{C}\right)\end{array}$ & Mean & SEM & $P$ value* \\
\hline & \multicolumn{4}{c}{$n$ mol $/ 10^{6}$ PMN at $5 \mathrm{~min}$} \\
Control & 7.22 & 0.64 & - \\
ANP $7-28\left(10^{-8} \mathrm{M}\right)$ & 10.62 & 0.55 & 0.0012 \\
TNF $(100 \mathrm{U} / \mathrm{ml})$ & 10.97 & 0.68 & 0.0002
\end{tabular}

Spontaneous reductions of cytochrome $c$ at $5 \mathrm{~min}$ of incubation at $37^{\circ} \mathrm{C}$ in the absence of PMA $(50 \mathrm{ng} / \mathrm{ml})$ by PMN that were preincubated for $45 \mathrm{~min}$ at $37^{\circ} \mathrm{C}$ in medium was $0.03 \pm 0.02 \mathrm{mmol} / 10^{6} \mathrm{PMN}$ (mean \pm SEM, $n=5$ ). * Student's $t$ test (two-tailed, paired), $n=6$.

cellular cyclic GMP accumulation (24). The level of cyclic GMP in PMN before addition of test substances was $29.3 \pm 2.61$ fmol $/ 10^{6} \mathrm{PMN}$ (mean $\pm \mathrm{SEM}, n=3$ ). At $10 \mathrm{~min}$ of incubation with the vehicle control, levels were $31.7 \pm 2.19(n=3)$. In the presence of $100 \mathrm{ng} / \mathrm{ml}$ of PMA, cyclic GMP accumulated to levels of $60.3 \pm 5.21 \mathrm{fmol} / 10^{6} \mathrm{PMN}(n=3)$, whereas $10 \mathrm{nmol} /$ liter of ANP 1-28 did not affect cyclic GMP content of PMN $\left(32.3 \pm 2.96 \mathrm{fmol} / 10^{6} \mathrm{PMN}, n=3\right)$.

\section{Discussion}

In this study we have demonstrated that although ANP in the absence of additional stimuli does not induce $\mathrm{PMN} \mathrm{O}_{2}^{-}$production, brief incubations of PMN with ANP markedly enhance the $\mathrm{O}_{2}^{-}$production in response to PMA, FMLP, or zymosan. A serum-free system was particularly critical for these experi-

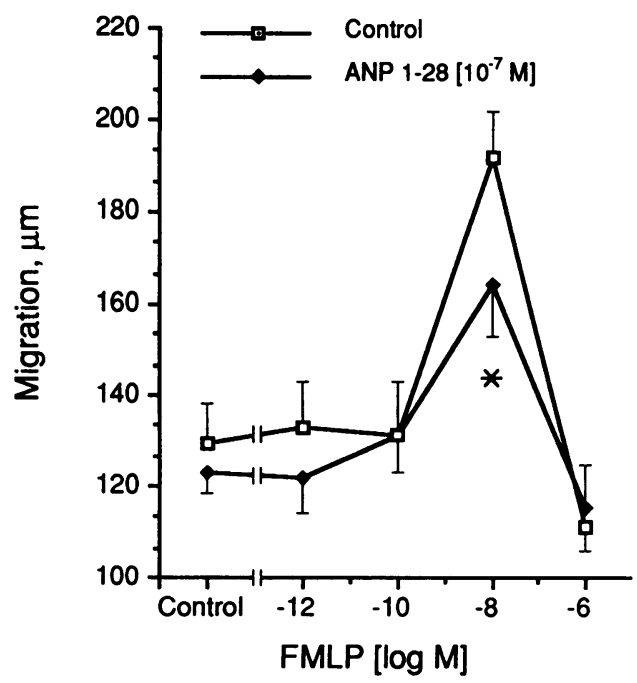

Figure 6. Migration of PMN into nitrocellulose micropore filters induced by different concentrations of FMLP in the presence ( $\square)$ or absence ( $\square$ ) of $10^{-7} \mathrm{M}$ of ANP 1-28. Mean \pm SEM distance on the $y$ axis of four separate experiments each performed in triplicate. Migration is significantly stimulated by FMLP (Kruskal-Wallis analysis of variance, $P=0.0005$ ) but not by $10^{-8} \mathrm{M}$ of ANP $1-28$ (control vs. ANP 1-28, $n=4 ; P>0.05$, Wilcoxon-Mann-Whitney test). Migration of PMN at $10^{-8} \mathrm{M}$ of FMLP is significantly inhibited by $\operatorname{ANP}\left({ }^{*} P\right.$ $<0.05$; Wilcoxon-Mann-Whitney test). Control is equal to migration in the absence of FMLP.

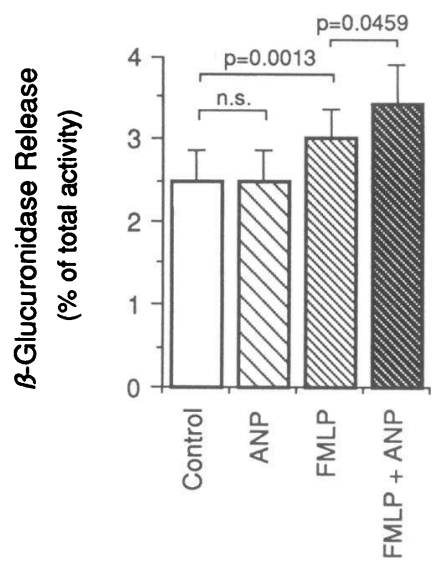

Figure 7. Effect of ANP on FMLP-induced release of $\beta$-glucuronidase from PMN. Cells $\left(2.5 \times 10^{7} / \mathrm{ml}\right)$ were incubated for $10 \mathrm{~min}$ at $37^{\circ} \mathrm{C}$ with medium, $10^{-7} \mathrm{M}$ of ANP 1-28, $10^{-7} \mathrm{M}$ of FMLP, or a combination of ANP 1-28 and FMLP at concentrations of $10^{-7} \mathrm{M}$ each. In six separate experiments, the total amount of $\beta$-glucuronidase present in unstimulated cells $(0.121 \pm 0.017$ $\mathrm{nmol} / \mathrm{min} \times 10^{6} \mathrm{PMN}$; mean \pm SEM), the amount released and that remaining in the cells were determined (recoveries were $96.6 \pm 1.68 \%$ for ANP $1-28$; $97.9 \pm 1.74 \%$ for FMLP; and $98.4 \pm 2.60 \%$ for ANP-plus-FMLP). The released activity is represented as the percentage of the total cell enzyme content (mean \pm SEM). $P$, probability by Student's $t$ test (two-tailed, paired).

ments because serum contains ANP (24). Using this approach, we have clearly demonstrated that ANP is similar to TNF- $\alpha$ in terms of its ability to prime PMN in vitro for enhanced respiration burst activity. After priming by ANP 1-28 or ANP 7-28, enhanced levels of NBT reduction or $\mathrm{O}_{2}^{-}$secretion could be triggered by either the soluble stimulant PMA or the more physiologic stimulants FMLP or opsonized zymosan.

The enhancement is dependent on the concentration of ANP and the conservation of the carboxy terminus of ANP. The concentrations of ANP, which were found to be active in vitro $(0.1-1 \mathrm{nmol} / \mathrm{liter})$ are well within the range of concentrations of ANP found in coronary sinus blood of humans in myocardial ischemia $(0.1-0.5 \mathrm{nmol} / \mathrm{liter})(22,24)$. The intactness of its disulfide bond may be important, inasmuch as only ANP 1-28 and ANP 7-28, but not ANP 1-11 or ANP 13-18 were seen to be active. It is known from previous studies that the natural hormone ANP 1-28 binds indiscriminately to the cyclase-coupled and noncoupled receptors of ANP (24). The amino-terminal domain of ANP contributes to the biological activity to a limited extent, and the removal of six amino-terminal residues up to $\mathrm{Cys}^{7}$ is tolerated without a dramatic change in the relaxation of smooth muscles or natriuresis (reviewed in reference 29). Our studies on activation of PMN respiration burst activity demonstrated no significant difference in the potencies of ANP 1-28 and ANP 7-28. Truncation of the peptide at the carboxy terminus of natural ANP with destruction of the ring structure abolished activity on PMN, as is known from studies on ANP structure-activity requirements employing other tissues for bio- or ligand-binding assays (29). Data obtained from the present study on levels of cyclic GMP in PMN after stimulation by ANP 1-28 suggest that the effect is mediated by the non-guanylate cyclyase-coupled receptor of ANP, inasmuch as ANP failed to stimulate cyclic GMP accumulation in PMN.

The significance of the finding of PMN activation by ANP is underlined by demonstration of other functions of PMN that are also affected by ANP. Although ANP alone does not induce release of significantly greater amounts of PMN lysosomal enzyme than the control untreated cells, it enhances the release of lysosomal enzyme in response to FMLP. Finally, presence of 
ANP in chemoattractant incubation media inhibited the FMLP-induced chemotaxis of PMN. Ward and Becker (30) described deactivation of chemotaxis toward a chemoattractant by incubation of PMN with a second stimulus, a phenomenon that, with FMLP, was shown to be due to cellular hyperadhesiveness (31). Similarly, PMN preincubated or incubated with potent PMN priming cytokines, such as TNF or GM-CSF (16), demonstrated a decrease in chemotaxis to FMLP through cellulose nitrate (32). We also observed that, in addition to TNF, other PMN priming factors such as human growth hormone, tuftsin, and tuftsin-like tachykinins, but not IL-2 or IL-3 inhibit chemotaxis through cellulose nitrate induced by FMLP or recombinant human IL-8 $(26,33)$. It was concluded that the decrease in chemotaxis by neutrophil priming cytokines described above is due to in vitro hyperadhesiveness of PMN to artificial surfaces causing reduced migration toward standard stimuli (32). The observed migration inhibition by ANP may thus reflect enhancement of PMN adhesiveness by ANP.

Although the molecular mechanisms involved in ANP activation of PMN for enhanced function are not yet defined, the fact that priming could be elicited with a variety of triggering agents that utilize distinct signal transduction pathways suggest some possible mechanisms. Previous studies have demonstrated effects of PMN-priming factors alone on PMN function. For example, TNF alone is a weak stimulant of $\mathrm{H}_{2} \mathrm{O}_{2}$ production, iodination, and lysozyme release; incubation times up to $90 \mathrm{~min}$ with the stimulant were required for the effects of the stimulant on PMN functional events to become evident (reviewed in reference 34). More potent effects of priming factors on PMN respiration burst activity were seen in recent studies when PMN were coincubated with priming factors and FMLP or PMA (35), or pretreated with factors and subsequently stimulated with soluble stimuli (36). In the present study, we observed that ANP enhanced oxidative burst and granule exocytosis in PMN when coincubated or when stimulated after pretreatment of PMN with FMLP, opsonized zymosan, or PMA.

GM-CSF up-regulates FMLP receptors on PMN, and GMCSF priming can be elicited with FMLP but not with PMA (37). Because enhanced $\mathrm{O}_{2}^{-}$secretion could be triggered by FMLP, zymosan, and PMA, it is unlikely that ANP enhances expression of receptors for all of these stimulating molecules. Instead, the priming induced by ANP may be related to enhanced signal transduction: e.g., enhanced expression of protein kinase $\mathrm{C}$ or augmented activity of the respiration burst or exocytotic systems.

The physiological role of preinflammatory factors in response to brief recurrent ischemia is the subject of intensive studies (for review, see reference 38). Endotoxin treatment in rats seems to be associated with protective effects on reperfusion injury (39). It will be important to see whether the active components of endotoxin, IL- 1 and TNF- $\alpha$, can protect the ischemic or reperfused heart and/or cause the expression of protective stress proteins (40). A rise in oxygen-derived free radicals after successful thrombolysis in myocardial infarction was recently reported (41) and such free radicals can induce synthesis of heat-shock proteins (42). However, it is not known whether ANP can induce stress proteins in vitro or in vivo. Our results add to the evidence for an important role of PMN in myocardial ischemia by demonstrating for the first time that ANP which is released from cardial myocytes may efficiently activate the functions of PMN.

\section{Acknowledgment}

The work was supported by the Austrian Science Funds, grant P-7476-Med.

\section{References}

1. Romson, J. L., B. G. Hook, S. L. Kunkel, G. D. Abraham, M. A. Schork, and B. R. Lucchesi. 1983. Reduction of the extent of ischemic myocardial injury by neutrophil depletion in the dog. Circulation. 67:1016-1023.

2. De Servi, S., A. Mazzone, G. Ricevuti, A. Fioravanti, E. Bramucci, L. Angoli, G. Stefano, and G. Specchia. 1990. Granulocyte activation after coronary angioplasty in humans. Circulation. 82:140-146.

3. Lipowsky, H. H., S. Usami, and S. Chien. 1980. In vivo measurement of "apparent viscosity" and microvessel hematocrit in the mesentery of the cat. Microvasc. Res. 19:297-319.

4. Engler, R. L., G. W. Schmid-Schoenbein, and R. S. Pavelec. 1983. Leukocyte capillary plugging myocardial ischemia and reperfusion in the dog. Am.J. Pathol. 111:98-111.

5. Kohchi, K., S. Takebayashi, T. Hiroki, and M. Nobuyoshi. 1985. Significance of adventitial inflammation of the coronary artery in patients with unstable angina: results at autopsy. Circulation. 71:709-716.

6. Engler, R. L., G. W. Schmid-Schoenbein, M. Dahlgren, and D. Morris. 1985. Leukocyte depletion prevents edema formation during one hour of myocardial ischemia. Fed. Proc. 44:821. (Abstr.)

7. Sommers, H. M., and R. B. Jennings. 1964. Experimental acute myocardial infarction: histologic and histochemical studies of early myocardial infarcts induced by temporary or permanent occlusion of a coronary artery. Lab. Invest. 13:1491-1503.

8. Mullane, K. M., R. Kraemer, and B. Smith. 1985. Myeloperoxidase activity as a quantitative assessment of neutrophil infiltration into ischemic myocardium. J. Pharmacol. Methods. 7:733-738.

9. Braunwald, E., and R. A. Kloner. 1985. Myocardial reperfusion: a doubleedged sword? J. Clin. Invest. 76:1713-1719.

10. Grisham, M. B., L. A. Hernandez, and D. N. Granger. 1986. Xanthine oxidase and neutrophil infiltration in intestinal ischemia. Am. J. Physiol. 251:G567-G574.

11. Rowe, G. T., N. H. Manson, M. Caplan, and M. L. Hess. 1983. Hydrogen peroxide and hydroxyl radical mediation for activated leukocyte depression of cardiac sarcoplasmic reticulum: participation of the cyclooxygenase pathway. Circ. Res. 53:584-591.

12. Mullane, K. M., N. Read, J. A. Salmon, and S. Moncada. 1984. Role of leukocytes in acute myocardial infarction in anesthetized dogs: relationship to myocardial salvage by anti-inflammatory drugs. J. Pharmacol. Exp. Ther. 228:510-522.

13. Tillmanns, H., H. Leinberger, F.-J. Neumann, M. Steinhausen, N. Parekh, and R. Zimmerman. 1984. Early microcirculatory changes during brief ischemia-primary events in ischemic myocardial injury? Circulation. 70(Suppl. II):88. (Abstr.)

14. Maury, C. P. J., and A. M. Teppo. 1989. Circulating tumor necrosis factor-alpha (cachectin) in myocardial infarction. J. Intern. Med. 225:333-336.

15. Tilg, H., J. Mair, M. Herold, W. E. Aulitzky, P. Lechleitner, F. Dienstl, and C. Huber. 1990. Acute phase response after myocardial infarction: correlation between serum levels of cytokines and C-reactive protein. Klin. Wochenschr. 68:1083.

16. Arai, K., F. Lee, A. Miyajima, S. Miyatake, N. Arai, and T. Yokota. 1990. Cytokines: coordinators of immune and inflammatory responses. Annu. Rev. Biochem. 59:783-836.

17. Vane, J. R., E. E. Änggård, and R. M. Botting. 1990. Regulatory function of the vascular endothelium. N. Engl. J. Med. 323:27-36.

18. Pohl, U. 1990. Endothelial cells as part of a vascular oxygen-sensing system: hypoxia-induced release of autacoids. Experientia. 46:1175-1179.

19. Skoglund, G., I. Cotgraeve, J. Rincon, M. Patarroyo, and M. IngelmanSundberg. 1988. $\mathrm{H}_{2} \mathrm{O}_{2}$ activates $\mathrm{CD} 1 \mathrm{lb} / \mathrm{CD} 18$-dependent cell adhesion. Biochem. Biophys. Res. Commun. 157:443-449.

20. Tainer, J. A., S. R. Turner, and W. S. Lynn. 1975. New aspects of chemotaxis: specific target cell attraction by lipid and lipoprotein fractions of Escherichia coli chemotactic factor. Am. J. Pathol. 81:401-410.

21. Said, S. I. 1990. Neuropeptides as modulators of injury and inflammation. Life Sci. 47:PL19-PL-21.

22. Wiedermann, C. J., Wiedermann, F. J., Herold, M., Tilg, H., Moes, N., Mühlberger, V., Beimpold, H., and Knapp, E. 1991. Plasma levels of atrial natriuretic peptide and tumor necrosis factor- $\alpha$ during transient myocardial ischemia in patients with stable angina. Klin. Wochenschr. 69:944.

23. Falcone, C., M. Totorici, C. Tosti Croce, C. Greco, R. Rinaldi, A. Salviati, A. Berni, A. Nigri, and A. Reale. 1990. Changes of beta-endorphin plasma levels during PTCA in patients with and without anginal pain. J. Am. Coll. Cardiol. 15:226A. (Abstr.) 
24. Brenner, B. M., B. J. Ballermann, M. E. Gunning, and M. L. Zeidel. 1990. Diverse biological actions of atrial natriuretic peptide. Physiol. Rev. 70:665-699.

25. Vollmar, A. M. 1990. Atrial natriuretic peptide in peripheral organs other than the heart. Klin. Wochenschr. 68:699-708.

26. Wiedermann, C. J., M. Niedermühlbichler, H. Beimpold, and H. Braunsteiner. 1991. Priming of normal human neutrophils by recombinant growth hormone. Br. J. Haematol. 78:19-22.

27. Pick, E. 1986. Microassays for superoxide and hydrogen peroxide production and nitroblue tetrazolium reduction using an enzyme immunoassay microplate reader. Methods Enzymol. 132:407-421.

28. Dewald, B., and M. Baggiolini. 1986. Methods for assessing exocytosis by neutrophils leukocytes. Methods Enzymol. 132:206-277.

29. Bovy, P. R. 1990. Structure activity in the atrial natriuretic peptide (ANP) family. Med. Res. Rev. 10:115-142.

30. Ward, P. A., and E. L. Becker. 1968. The deactivation of rabbit neutrophils by chemotactic factor and the nature of activatable esterases. J. Exp. Med. 127:693-709.

31. Fehr, J., and C. Dahinden. 1979. Modulating influence of chemotactic factor-induced cell adhesiveness on granulocyte function. J. Clin. Invest. 64:8-16.

32. Schleifenbaum, B., R. Moser, and J. Fehr. 1990. A defect in chemotaxis from interleukin-2. N. Engl. J. Med. 323:682-683. (Lett.)

33 Wiedermann, C. J., M. Niedermühlbichler, U. Zilian, D. Geissler, I. Lindley, and H. Braunsteiner. 1991. Priming of normal human neutropils by tachykinins: tuftsin-like inhibition of in vitro chemotaxis stimulated by formylpeptide or interleukin-8. Regul. Pept. 36: 359-368.
34. Steinbeck, M. J., and J. A. Roth. 1989. Neutrophil activation by recombinant cytokines. Rev. Infect. Dis. 11:549-568.

35. Shalaby, M. R., M. A. Palladino, Jr., S. E. Hirabayashi, T. E. Eessalu, G. D. Lewis, H. M. Shepard, and B. B. Aggarwal. 1987. Receptor binding and activation of polymorphonuclear neutrophils by tumor necrosis factor-alpha. $J$. Leukocyte Biol. 41:196-201.

36. Berkow, R. L., D. Wang, J. W. Larrick, R. W. Dodson, and T. H. Howard. 1987. Enhancement of neutrophil superoxide production by preincubation with recombinant human tumor necrosis factor. J. Immunol. 139:3783-3791.

37. English, D. H., H. E. Broxmeyer, T. G. Gabig, L. P. Akard, D. E. Williams, and $\mathbf{R}$. Hoffman. 1988. Temporal adaptation of neutrophil oxidative responsiveness to $n$-formyl-methionyl-leucyl-phenylalanine: acceleration by granulocytemacrophage colony stimulating factor. J. Immunol. 141:2400-2405.

38. Editorial. 1991. Stress proteins and myocardial protection. Lancet. 377:271-272.

39. Brown, J. M., M. A. Grosso, L. S. Terada, G. J. R. Whitman, A. Banerjee, C. W. White, Alden H. Harken, and J. E. Repine. 1989. Endotoxin pretreatment increases endogenous myocardial catalase activity and decreases ischemia-reperfusion injury of isolated rat hearts. Proc. Natl. Acad. Sci. USA. 86:2516-2520.

40. Tilg, H., J. Mair, M. Herold, and F. Dienstl. 1991. Stress proteins and myocardial protection: is there a role for tumor necrosis factor? Lancet. 337:677 (letter).

41. Davies, S. W., K. Ranjadayalan, and D. G. Wickens. 1990. Lipid peroxidation associated with successful thrombolysis. Lancet. 335:741-743.

42. Polla, B. S. 1988. A role for heat shock proteins in inflammation? Immunol. Today. 9:134-137. 